\title{
The society for environmental Geochemistry and health (SEGH): a retrospect
}

\author{
Bobby G. Wixson · Brian E. Davies
}

Published online: 22 February 2019

(C) Springer Nature B.V. 2019

In 2007, following a lack of interest by the US Government and reduced funding for travel and conferences at universities SEGH membership in the US decreased steadily and drastically. At the same time, in Europe interest and numbers were increasing. Recognizing this emerging and strong geographical focus administration of SEGH has been transferred to the European section. SEGH in the USA was an Incorporated organization in the state of Missouri and was therefore governed by Incorporation rules for the collection and distribution of dues, election of officers and conduct of meetings. These rules were different from the European section.

In order for the European section, and therefore SEGH in general, to succeed and grow, the US SEGH was closed on August of 2018. Remaining US SEGH members will be transferred to the European SEGH. We hope it will be successful and become truly international. We express our thanks to all those who have provided leadership and who have worked hard over the years.

We offer this short account of the past to help new members to know where we came from and we are proud of what was achieved.

B. G. Wixson · B. E. Davies ( $₫)$

Emeritus College, Clemson University, Clemson, SC,

USA

e-mail: bdavies@clemson.edu

\section{In the beginning}

SEGH was born in Dallas, Texas, on December 30, 1968, at a symposium on 'Environmental Geochemistry in Health and Disease.' Some 31 participants discussed ways to promote this marriage of environmental science and epidemiology. An ad hoc committee was formed with Howard C. Hopps (pathologist) and Helen L. Cannon (biogeochemist) as Co-Chairmen Delbert Hemphill and Carl Marienfeld proposed holding a meeting in June 1969 at the University of Missouri-Columbia in conjunction with the 3rd Annual 'Conference on Trace Substances in Environmental Health.' At the 1970 meeting, the name 'Society for Environmental Geochemistry and Health (SEGH)' was approved and Delbert Hemphill was elected as the first President. Both of us became members that year.

Later, SEGH was incorporated in the State of Missouri, USA, and thereby attained a tax-free status organization with the US Revenue service (IRS). This required a formal constitution and rules for collecting fees and electing officers. Throughout the years, Bobby Wixson and Nord Gale served SEGH by acting as the formal Secretary and Treasurer and were responsible for making all reports required by the state.

SEGH continued to hold its annual meetings during the Trace Substances Conference at University of Missouri-Columbia until 1993 when the conference 
series ended. At these meetings, many close friendship were formed at its social events: the annual barbeque, canoe floats on the Current River (a National Scenic Waterway in Missouri) and in group expeditions to local entertainment 'hot spots.'

\section{National academy of sciences subcommittee}

In 1969, the US National research academy (NRC) approved a subcommittee on the 'Geochemical environment in relation to health and disease (GERHD)' to conduct national workshops on geochemistry and the environment. Many future SEGH officers and members served on this subcommittee. A trilogy of reports were published on Geochemistry and the environment in 1972, 1973 and 1974 as well as panel studies and reports on (1) The Geochemistry of water in relation to cardiovascular disease and (2) Trace-element Geochemistry of coal resource development related to environmental quality and health, (3) Aging and the geochemical environment and (4) Geochemical environment and urolithiasis.

\section{An emerging national focus for SEGH}

In the mid-1980s, regulatory agencies in the USA noted the lack of recognized guidelines for acceptable concentrations of lead in soil for health protection and remediating contaminated land. A SEGH conference was held resulting in a publication (1988) on lead in soil: issues and guidelines. This in turn led to a task force co-chaired by Bobby Wixson and Brian Davies, and its work resulted in the publication (1993) of SEGH 'Lead in soil: recommended guidelines' by Science Reviews which was utilized by international decision makers and contributed to the 2002 UK DEFRA publication 'Soil guideline values for lead contamination.'

A second SEGH task force on arsenic was formed in 1991 chaired by Willard Chappell and Charles Abernathy who organized conferences in 1993, 1995 and 2000. The final report was utilized by the US EPA and other countries through out the world for arsenic in drinking water guidelines.

\section{European section of SEGH}

During the 1980s, both the American and European universities and research institution experienced increasing travel funding reduction and difficulty in attending international meetings. In Britain, at that time there were approximately a dozen individuals who had faithfully attended the Missouri conferences. Their interest was strong, but lack of travel funds made continuing membership of SEGH questionable.

In 1982, Brian Davies hosted Bobby Wixson for a field trip in west Wales to visit some abandoned lead mines and to discuss how further to promote their collaboration on lead pollution. During a pub lunch, the future of SEGH was discussed in light of the worsening financial support climate. The idea emerged that in order to retain the British membership, European meetings should be organized as part of SEGH outreach. The SEGH board approved this. European section officers were elected, and three successive meetings were organized by Brian Davies in Birmingham, England, starting in 1982. As they say, the rest is history.

\section{Asia-Pacific section of SEGH}

Many colleagues in SEGH indicated a desire to develop a section of SEGH in the Asia-Pacific area, and Xiangdon Li with the help of Iain Thornton and Ron Fuge made a proposal to the SEGH board for a new section. The Asia-Pacific section was formed along with the first symposium on environmental Geochemistry in Hong Kong in November 1998, and additional conferences have been held in South Korea and China.

\section{A research journal}

Over its early years, SEGH activities and brief notes on members' research were published in the in-house 'Interface.' Some full research papers were published in 'Minerals and the Environment' from 1979 to 1985. In 1985, this obscure journal was reorganized and rebadged as 'Environmental Geochemistry and Health' under the editorship of Brian Davies with generous support by the then publisher Peter Farago. Peter commissioned a design artist to create the 
present society logo to replace the old one which he often described as a demented spider.

All SEGH members were encouraged to support the new journal, and receipt of print copies became a membership benefit. The journal has since gone through several changes in ownership and in 2003 Ming Wong became the new editor.

\section{SEGH awards}

Past Presidents have been generous in providing additional funding to support SEGH activities.

1. The Hemphill Award given to students for the best presentation of a research paper at the conference or the best research poster paper.

2. The J. Julian Chisolm, Jr Award given to a SEGH member who has shown exceptional leadership in bringing recognition to the SEGH.

\section{SEGH and its future}

Naturally, we are both sad that after half a century, SEGH as a formal Incorporated body in the USA has had to close. We look back with pride at what we have contributed and what has been achieved and we owe a deep debt of gratitude to the many who worked with us to make SEGH a success over 50 years. Times change, however, and we have to change with them. The cup is half full not half empty, and we are confident that the reorganized SEGH will strengthen and grow and continue to serve society at large by promoting the message that environmental geochemistry really does affect human health.

Publisher's Note Springer Nature remains neutral with regard to jurisdictional claims in published maps and institutional affiliations. 